\title{
Performance of low birth-weight piglets upon protein-energy and/or colostrum supplementation
}

\author{
[Desempenho de leitões de baixo peso ao nascimento submetidos à suplementação \\ proteico-energética com ou sem colostro] \\ R.C. Viott ${ }^{1}$, T.A. Menezes ${ }^{1}$, A.P.G. Mellagi ${ }^{2}$, M.L. Bernardi ${ }^{3}$, I. Wentz $^{2}$, F.P. Bortolozzo ${ }^{2 *}$ \\ ${ }^{1}$ Aluno de pós-graduação - FV - Universidade Federal do Rio Grande do Sul - Porto Alegre, RS \\ ${ }^{2}$ Faculdade de Veterinária - Universidade Federal do Rio Grande do Sul - Porto Alegre, RS \\ ${ }^{3}$ Faculdade de Agronomia - Universidade Federal do Rio Grande do Sul - Porto Alegre, RS
}

\begin{abstract}
The study aimed to investigate the effect of oral protein-energy supplement (OPES) and/or extra colostrum within the first few hours of life on the survival and growth performance of low birth-weight piglets during the suckling period. Based upon nutritional strategy, low-birth-weight piglets $(804-1309 \mathrm{~g})$ were randomly allocated into four groups: COS0 (control group, $n=300)$ - no supplementation; C1S0 ( $\mathrm{n}=$ $299)$ - supplementation with $50 \mathrm{~mL}$ of a colostrum pool through an orogastric tube; COS1 $(\mathrm{n}=298)$ - oral supplementation with $8 \mathrm{~mL}$ oral OPES; C1S1 $(\mathrm{n}=297)$ - supplementation with both $50 \mathrm{~mL}$ of colostrum and $8 \mathrm{~mL}$ of OPES. The piglets' body weight was monitored at birth, $24 \mathrm{~h}$ after birth, on day 7, day 14 and day 20 post-partum. Both colostrum and protein-energy supplementations did not affect $(\mathrm{P}>0.05)$ colostrum intake $(253.6 \mathrm{~g} ; 259.4 \mathrm{~g} ; 259.4 \mathrm{~g} ; 263.8 \mathrm{~g}$ for COS0, C1S0, COS1, C1S1, respectively), weight gain during the first $24 \mathrm{~h}(62.6 \mathrm{~g} ; 68.3 \mathrm{~g} ; 67.1 \mathrm{~g}$ and $69.8 \mathrm{~g}$ for COSO, C1S0, C0S1, C1S1, respectively) and pre-weaning mortality $(11.3 \%, 11.4 \%, 12.4 \%$ and $9.4 \%$ for COS0, C1S0, COS1, C1S1, respectively). Administration of OPES increased $(\mathrm{P}=0.032)$ the average daily weight gain from birth till weaning $(189.1$ vs. $182.3 \mathrm{~g})$ and tended to increase the weight of the piglets $(\mathrm{P}=0.060)$ at weaning (4893.1 vs. 4746.4g for OPES and no OPES, respectively). In conclusion, nutritional manipulation does not affect colostrum intake and pre-weaning mortality of low birth-weight piglets. However, body weight gain during the suckling period and the weight at weaning were observed to be marginally improved by administration of OPES.
\end{abstract}

Keywords: supplementation, colostrum, weight gain, mortality

\section{RESUMO}

O objetivo do trabalho foi avaliar o efeito da suplementação oral de suplemento proteico-energético (OPES) elou colostro adicional nas primeiras horas de vida sobre a sobrevivência e o desempenho de leitões de baixo peso na fase de maternidade. Foram utilizados leitões com peso entre 804 e $1.309 \mathrm{~g}$ ao nascimento, alocados aleatoriamente em quatro grupos, de acordo com a estratégia nutricional: COSO (grupo controle, $n=300)$ - sem suplementação; C1SO $(n=299)$ - fornecimento de $50 \mathrm{~mL}$ de colostro, via sonda orogástrica; COS1 ( $n=298)$ - fornecimento de 8mL de OPES; CIS1 ( $n=297)$ - fornecimento de $50 \mathrm{~mL}$ de colostro $+8 \mathrm{~mL}$ de OPES. Os leitões foram pesados ao nascimento, $24 \mathrm{~h}$, e nos dias sete, 14 e 20 de vida. O fornecimento de colostro ou de OPES não afetou $(P>0,05)$ o consumo de colostro $(253,6 \mathrm{~g}$; 259,4g; 259,4g; 263,8g para COSO, C1SO, COS1, C1S1, respectivamente), o ganho de peso nas primeiras $24 \mathrm{~h}$ (62,6g; 68,3g; 67,1g e 69,8g para COSO, C1SO, COS1, ClS1, respectivamente) e a taxa de mortalidade $(11,3 \%, 11,4 \%, 12,4 \%$ e 9,4\% para COSO, C1SO, COS1, C1S1, respectivamente). A suplementação com OPES aumentou $(P<0,05)$ o ganho de peso diário do nascimento ao desmame $(189,1 \mathrm{~g}$ vs. $182,3 \mathrm{~g})$ e tendeu a aumentar o peso dos leitões $(P=0,060)$ ao desmame $(4893,1$ vs. $4746,4 \mathrm{~g}$

Recebido em 7 de fevereiro de 2017

Aceito em 10 de maio de 2017

*Autor para correspondência (corresponding author)

E-mail: fpbortol@ufrgs.br 
para OPES e sem OPES, respectivamente). Conclui-se que a manipulação nutricional de leitões de baixo peso ao nascimento não afeta o consumo de colostro e a mortalidade pré-desmame. No entanto, a administração de OPES aumentou levemente o ganho de peso na maternidade e o peso ao desmame.

Palavras-chave: suplementação, colostro, ganho de peso, mortalidade

\section{INTRODUCTION}

Advances in genetics and techniques associated with the production of pigs have resulted in significantly larger litters (Baxter et al., 2013). Over the last 20 years, litter sizes have increased to $14-16$ piglets, which is an improvement of nearly 2-4 pigs per litter (Quesnel et al., 2015). However, a larger litter size is often associated with a reduced birth weight and a greater weightbased variation within the litter (Quiniou et al., 2002). This has a negative impact on piglet vitality as well as survival (Damgaard et al., 2003).

Weight at birth is regarded as an important indicator of performance because piglets with low birth-weight (less than $1.0 \mathrm{~kg}$ ) are known to be associated with a reduced potential for growth (Foxcroft et al., 2009). This effect is often observed to persist throughout life with the lighter piglets taking significantly longer to reach market (Beaulieu et al., 2010) and having poorer carcass quality as compared to their heavier counterparts (Foxcroft et al., 2009). Low birthweight piglets also suffer from a higher risk of death because they are less competitive with respect to colostrum intake and have lower body energy reserves (Baxter et al., 2008). The mortality rate among these low-weight piglets ranges 30-70\% (Morise et al., 2008; Furtado et al., 2012; Panzardi et al., 2013).

In addition to limited body energy reserves at birth, light-weight piglets often do not receive adequate plasma immunoglobulins during pregnancy due to certain structural characteristics of the swine placenta (Salmon et $a l ., 2009$ ) and hence are susceptible to a large variety of pathogens present in the environment. As a result, colostrum intake soon after birth is vital for ensuring the survival of these piglets as colostrum provides immunoglobulins (Devillers et al., 2011; Ferrari et al., 2014) as well as the energy required for thermoregulation and body growth (Le Dividich et al., 2005). It is recommended that a minimum of $200 \mathrm{~g}$ of colostrum should be consumed during the first
$24 \mathrm{~h}$ of life so as to reduce the chances of death until weaning (Quesnel et al., 2012) and 250g should be achieved for a higher pre and postweaning performance (Quesnel et al., 2012; Ferrari et al., 2014).

Administration of energy supplements is a strategy that is frequently used in order to provide the neonatal piglet with the energy it requires for improving the intake of colostrum (Declerck et al., 2016). The extra energy provided in this manner has the potential to improve their ability to search for the udder, which in turn can increase the intake of colostrum and improve performance while decreasing mortality until weaning (Quesnel et al., 2012). However, very few studies have been conducted to assess the effect of extra energy supplementation in the first hours of life and the results of these studies are inconsistent (Casellas et al., 2005; Kummer et al., 2015; Declerck et $a l ., 2016)$. The present study was conducted with the aim of investigating the effect of oral proteinenergy supplement (OPES) and/or extra colostrum within the first few hours of life on the survival and growth performance of low birthweight piglets during the suckling period.

\section{MATERIAL AND METHODS}

The experimental protocol described in this study was approved by the Institutional Animal Care and Use Committee (CEUA-FAVET-UFRGS) under an experimental license (Project number 28456). The trial was carried out on a commercial swine unit of 4,300 sows, located in the South of Brazil in the Santa Catarina state. The study was conducted during the months of January to May. Piglets with birth weight 804$1,309 \mathrm{~g}$ were selected from multiparous 292 Landrace $\times$ Large White sows (Camborough $25^{\circledR}$, Agroceres PIC) with parity order (PO) of $4.7 \pm 0.08$ (mean \pm SEM)

From day 110 of gestation onwards, the females were housed in farrowing rooms in individual crates of dimensions $2.10 \times 1.70 \mathrm{~m}$. The internal temperature of the farrowing room was 
controlled by double curtain management. The farrowing crates had a place of refuge for the piglets (dimensions of $0.75 \times 0.65 \mathrm{~m}$ ) and free access to a creep area with a heating floor system and incandescent lamp. Sows were fed nearly $a d$ libitum (18.5\% CP; $1.0 \%$ Lysin, 3,400kcal $\mathrm{EM} / \mathrm{kg}$ ) with automatic feeder system. Both females and piglets had ad libitum access to water.

For establishing a litter of 12 low birth-weight piglets, 2 to 5 farrowings were monitored simultaneously. In total, 292 farrowings were monitored over a period of 98 days. Piglet care at birth included drying, clamping, and antisepsis of the umbilical cord. Subsequent to these procedures, the neonates were individually weighed and placed close to the mother's udder in the farrowing crate where an infrared heating lamp was set above them.

Healthy non-experimental sows with body condition score between 2.5 and 4.0 (scale of 1 to 5) and PO between 2 to 9 were used to form the colostrum pools. Colostrum extraction was performed by manual milking within $6 \mathrm{~h}$ of onset of farrowing. Colostrum samples $(\sim 200 \mathrm{~mL})$ were collected and grouped to form pools of $1,200 \mathrm{~mL}$ each. These pools were stored at $-20^{\circ} \mathrm{C}$ and care was taken to ensure that storage period does not exceed 7 days. Immediately before use, the colostrum was thawed in a $40^{\circ} \mathrm{C}$ water bath for $40 \mathrm{~min}$.

Piglets were divided into four groups: (a) Control (COS0), (b) Colostrum (C1S0), (c) OPES (COS1) and, (d) Colostrum + OPES (C1S1). All piglets were suckled by their biological mothers during the first $24 \mathrm{~h}$ of life, and for the COS0 group, no further supplementation was performed. In C1S0 group, piglets received an additional $50 \mathrm{~mL}$ of colostrum (from a colostrum pool) through an orogastric tube (Tube No. 08, Mark Med. Bragança Paulista, SP, Brazil). Piglets from the COS1 group orally received $8 \mathrm{~mL}$ of OPES (Mig Dose Evolution ${ }^{\circledR}$, MIG PLUS Agroindustrial, Brazil). The OPES formulation (Tab. 1) was predominantly composed of milk whey proteins, refined coconut oil and lactose. The C1S1 group received $50 \mathrm{~mL}$ of colostrum $+8 \mathrm{~mL}$ of OPES.

The total volume of colostrum or OPES was fractionated in two doses of equal volume at 1 and $4 \mathrm{~h}$ after birth in the C1S0, COS1, and C1S1 groups.

Table 1. Composition of the product supplied to the piglets and corresponding value for $8 \mathrm{~mL}$

\begin{tabular}{ccc}
\hline Component & Quantity $($ per kg) & Offered in $8 \mathrm{~mL}^{*}$ \\
\hline Butyric acid (min) & $5,000 \mathrm{mg}$ & $12 \mathrm{mg}$ \\
Calcium (min - max) & $2,500-5,000 \mathrm{mg}$ & $6-12 \mathrm{mg}$ \\
Chrome (min) & $0.4 \mathrm{mg}$ & $0.00096 \mathrm{mg}$ \\
Metabolizable Energy (min) & $5,400 \mathrm{kcal}$ & $12.96 \mathrm{kcal}$ \\
Crude fat (min) & $400 \mathrm{~g}$ & $960 \mathrm{mg}$ \\
Crude fiber (max) & $10 \mathrm{mg}$ & $0.024 \mathrm{mg}$ \\
Phosphorus (min) & $1,500 \mathrm{mg}$ & $3.6 \mathrm{mg}$ \\
L-Carnitine (min) & $20.8 \mathrm{~g}$ & $49.92 \mathrm{mg}$ \\
Lactose (min) & $200 \mathrm{~g}$ & $480 \mathrm{mg}$ \\
Lysine (min) & $15 \mathrm{~g}$ & $36 \mathrm{mg}$ \\
Mineral (max) & $60 \mathrm{~g}$ & $144 \mathrm{mg}$ \\
Methionine (min) & $4,000 \mathrm{mg}$ & $9.6 \mathrm{mg}$ \\
Nucleotides (min) & $2,000 \mathrm{mg}$ & $4.8 \mathrm{mg}$ \\
Crude Protein (min) & $200 \mathrm{~g}$ & $480 \mathrm{mg}$ \\
Humidity (max) & $60 \mathrm{~g}$ & $144 \mathrm{mg}$ \\
Vitamin E (min) & $300 \mathrm{mg}$ & $0.72 \mathrm{mg}$ \\
\hline
\end{tabular}

Guaranteed levels of the product MIG Dose Evolution ${ }^{\circledR}$, as informed by the manufacturer.

* Solution of $2.4 \mathrm{~g}$ supplement plus $8 \mathrm{~mL}$ water q.s., according to the manufacturer's instructions. 
The piglets, after $24.4 \pm 0.04 \mathrm{~h}$ of birth, were cross-fostered so as to form litters containing three piglets from each group. In total, 100 litters with 12 piglets each were formed for the purpose of this study. The piglets that died before crossfostering were replaced by piglets of the same $\mathrm{BW}$ range and age; however, these piglets were not included for analysis purposes.

The piglets were individually weighed at birth and after $24 \mathrm{~h}$ in order to determine weight gain on the first day of life. Colostrum consumption was estimated according to the formula defined by Devillers et al. (2004) presuming 30min as the time interval between birth and the first suckling. The piglets were also weighed at 7,14 and 20 days of age (D7, D14 and D20, respectively).

Statistical analysis was performed using the Statistical Analysis System software (Statistical..., 2010). Depending on the variable concerned, data were presented either as LSmean \pm standard error of the mean or as a percentage. The differences were considered as significant at $\mathrm{P}<0.05$ or as trends for $\mathrm{P}$-values between 0.05 and 0.10 . The experiment had a factorial design of $2 \times 2$, with two factors (colostrum and OPES) and two levels (with and without administration). In all the models of analysis that were employed in this study, colostrum, OPES, and their interactions were included as fixed effects. For continuous variables, LSmeans were compared by the Tukey-Kramer test.

The following variables were analyzed for verifying the uniformity of the groups at the beginning of the experiment: PO of the foster female, the interval between birth and crossfostering, and the number of total born and born alive piglets.

The cumulative mortality of piglets up to 7,14 and 20 days of age was analyzed as a binary variable using the GLIMMIX procedure wherein the piglet was regarded as the experimental unit. Litter and PO of foster mothers were included as random effects.

Considering the litter as the experimental unit (the average of the three piglets of each group within each litter), colostrum consumption, weight gain in the first $24 \mathrm{~h}$ and average daily weight gain (ADG) from birth to weaning were analyzed using the MIXED procedure. For analysis of colostrum consumption and weight gain up to $24 \mathrm{~h}$, the number of piglets born alive was considered as a covariate $(\mathrm{P}<0.05)$ while the PO of the biological mother was excluded from the model as it was regarded as non-significant.

For body weight analysis after cross-fostering, litter and PO of foster mothers were included as random effects. The weight was analyzed as repeated measures using the MIXED procedure, considering the experimental unit the average of 3 piglets in each litter and including the fixed effects of day of weighing, colostrum and OPES administration and their interactions.

\section{RESULTS}

Three litters used in this study included 11 instead of 12 piglets, because it was not possible to get three piglets within the same weight range of their counterparts. In these litters, the COS1, $\mathrm{C} 1 \mathrm{~S} 0$ and C1S1 groups were composed of only two piglets instead of three. Also, three piglets were excluded from the analysis, one of them by death due to failure to pass the tube (C1S1), one death due to hemorrhage (COS1) and one death due to lung malformation (C1S1).

No significant difference $(\mathrm{P}>0.05)$ was observed regarding the average birth weight (1.097 \pm $3.87 \mathrm{~g}$ ), number of piglets born alive (14.31 \pm $0.09)$, PO of biological mother (4.66 \pm 0.08$)$, interval between birth and cross-fostering (24.42 $\pm 0.06 \mathrm{~h})$ and the percentage of male and female piglets (50.67 and $49.33 \%$, respectively). This result endorses the uniformity of the groups at the beginning of the trial.

No impact of colostrum, OPES or their interaction $(\mathrm{P}>0.05)$ was observed on the cumulative mortality at 3,7 and 20 days of age (Tab. 2). The overall pre-weaning mortality rate was determined to be $11.1 \%$ and the major causes of death were crushing (5.36\%), starvation $(2.09 \%)$ and diarrhea (1.76\%); no effect of colostrum, OPES and their interaction was observed $(\mathrm{P}>0.05)$. 
Table 2. Percentages of preweaning mortality (up to 3, 7, and 20 days after birth) in low birth-weight piglets, according to colostrum and/or OPES supplementation within the first hours of life

\begin{tabular}{llllllll} 
& C0S0 & C1S0 & C0S1 & C1S1 & P-value & & \\
\hline Mortality & $(\mathrm{n}=300)$ & $(\mathrm{n}=299)$ & $(\mathrm{n}=298)$ & $(\mathrm{n}=297)$ & $\begin{array}{l}\text { Colostru } \\
\mathrm{m}\end{array}$ & OPES & Interaction \\
\hline Up to 3 days & 6.7 & 6.3 & 4.7 & 5.4 & 0.858 & 0.276 & 0.699 \\
Up to 7 days & 9.3 & 8.4 & 8.4 & 7.1 & 0.456 & 0.479 & 0.875 \\
Up to 20 days & 11.3 & 11.4 & 12.4 & 9.4 & 0.392 & 0.775 & 0.394
\end{tabular}

OPES = oral protein-energy supplement; $\mathrm{C} 0 \mathrm{~S} 0=$ no supplement; $\mathrm{C} 1 \mathrm{~S} 0=50 \mathrm{~mL}$ of colostrum; $\mathrm{C} 0 \mathrm{~S} 1=8 \mathrm{~mL}$ of OPES ; $\mathrm{C} 1 \mathrm{~S} 1=50 \mathrm{~mL}$ of colostrum and $8 \mathrm{~mL}$ of OPES.

The results regarding colostrum intake, weight gain at day 1 of the age and ADG during the suckling period are presented in Tab. 3. Colostrum, OPES and their interaction had no impact on colostrum intake and weight gain in the first $24 \mathrm{~h}$ after birth $(\mathrm{P}>0.05)$. OPES was seen to have a positive impact on ADG until weaning $(\mathrm{P}<0.05)$ with a higher ADG observed for piglets that received OPES (COS1 and $\mathrm{C} 1 \mathrm{~S} 1$ groups; $189.1 \mathrm{~g})$ as compared to those that did not (COSO and C1S0 groups; 182.3g).

Table 3. Colostrum intake, weight gain in the first day of life, and average daily gain (ADG) of suckling piglets according to the colostrum and/or OPES supplementation within the first hours of life

\begin{tabular}{|c|c|c|c|c|c|c|c|c|}
\hline \multirow{2}{*}{ Variable } & \multirow{2}{*}{$\begin{array}{l}\text { C0S0 } \\
(n=300)\end{array}$} & \multirow{2}{*}{$\begin{array}{l}\text { C1S0 } \\
(\mathrm{n}=299)\end{array}$} & \multirow{2}{*}{$\begin{array}{l}\text { C0S1 } \\
(\mathrm{n}=298)\end{array}$} & \multirow{2}{*}{$\begin{array}{l}\text { C1S1 } \\
(n=297)\end{array}$} & \multirow{2}{*}{ SEM } & \multicolumn{3}{|l|}{ P-value } \\
\hline & & & & & & Colostrum & OPES & Interaction \\
\hline \multicolumn{9}{|c|}{ Colostrum intake, $\mathrm{g}$} \\
\hline & 253.6 & 259.4 & 259.4 & 263.8 & 6.71 & 0.447 & 0.448 & 0.924 \\
\hline \multicolumn{9}{|c|}{ Weight gain at first day, $g$} \\
\hline & 62.6 & 68.3 & 67.1 & 69.8 & 5.19 & 0.416 & 0.569 & 0.777 \\
\hline \multicolumn{9}{|c|}{ ADG from birth until weaning } \\
\hline & 182.2 & 182.4 & 191.0 & 187.3 & 4.30 & 0.588 & 0.032 & 0.540 \\
\hline
\end{tabular}

$\mathrm{SEM}=$ Standard error of mean; OPES = oral protein-energy supplement; C0S0 = no supplement; C1S0 $=50 \mathrm{~mL}$ of colostrum; $\mathrm{C} 0 \mathrm{~S} 1=8 \mathrm{~mL}$ of OPES; $\mathrm{C} 1 \mathrm{~S} 1=50 \mathrm{~mL}$ of colostrum and $8 \mathrm{~mL}$ of OPES.

Although the weight of the piglets (Tab. 4) was not affected $(\mathrm{P}>0.05)$ by colostrum or the interaction between colostrum and OPES, it was affected by supplementation with OPES alone
$(\mathrm{P}=0.06)$. Weight at weaning was $4.75 \mathrm{~kg}$ for non-supplemented piglets (COS0 and C1S0) as compared to $4.89 \mathrm{~kg}$ for the supplemented (COSO and $\mathrm{C} 1 \mathrm{~S} 0)$ pigs.

Table 4. Effect of colostrum and OPES administration on weight and average daily gain (ADG) in newborn low birth-weight piglets, analyzed as repeated measures

\begin{tabular}{lllllll} 
Variables & $\begin{array}{l}\text { COS0 } \\
(\mathrm{n}=100)\end{array}$ & $\begin{array}{l}\text { C1S0 } \\
(\mathrm{n}=100)\end{array}$ & $\begin{array}{l}\text { COS1 } \\
(\mathrm{n}=100)\end{array}$ & $\begin{array}{l}\text { C1S1 } \\
(\mathrm{n}=100)\end{array}$ & Mean & SEM \\
\hline Weight, $\mathrm{g}$ & & & & & & \\
D7 & 2082.6 & 2075.3 & 2101.5 & 2097.3 & 2089.2 & 42.7 \\
D14 & 3460.9 & 3438.6 & 3558.7 & 3493.0 & 3487.8 & 42.7 \\
D20 & 4741.8 & 4751.0 & 4931.4 & 4854.9 & 4819.8 & 42.7 \\
Mean & 3428.4 & 3421.6 & 3530.5 & 3481.7 & & \\
SEM & 54.9 & 55.1 & 54.9 & 54.9 & & \\
\hline
\end{tabular}

The analysis considered the average of three piglets for each group in 100 litters.

The weight of the piglets tended to be affected by OPES administration $(\mathrm{P}=0.063)$, but it was not affected by colostrum or their interaction $(\mathrm{P}>0.05)$. There was an effect of the moment of weighing $(\mathrm{P}<0.001)$, but not the interaction between colostrum and moment or OPES and moment $(\mathrm{P}>0.05)$.

$\mathrm{SEM}=$ Standard error of mean; OPES $=$ oral protein-energy supplement; $\mathrm{C} 0 \mathrm{~S} 0=$ no supplement; $\mathrm{C} 1 \mathrm{~S} 0=50 \mathrm{~mL}$ of colostrum; $\mathrm{C} 0 \mathrm{~S} 1=8 \mathrm{~mL}$ of OPES$; \mathrm{C} 1 \mathrm{~S} 1=50 \mathrm{~mL}$ of colostrum and $8 \mathrm{~mL}$ of OPES. 


\section{DISCUSSION}

The neonatal pig metabolism is extremely efficient at retaining colostrum as well as other nutritional supplements. However, studies regarding the use of oral protein-energy supplements associated with an extra colostrum supplementation in neonatal piglets are scarce. The present study was conceptualized with the aim of evaluating the efficiency of nutritional strategies such as administration of extra colostrum and protein-energy supplement on factors such as mortality rate, colostrum intake, and weight gain on the first day of life as well as during the suckling period of low birth-weight piglets. Although colostrum or OPES supplementation was not observed to impact mortality rate or colostrum intake, it was seen that OPES administration influenced both ADG and weight of the piglets.

Body weight at birth is an important indicator of weight at weaning, as piglets with low birthweight tend to exhibit a reduced growth rate and weigh less at the end of the suckling period (Quiniou et al., 2002). Our findings regarding ADG and weight at weaning (186.3g/d and $4820.3 \mathrm{~g}$, respectively) are comparable to those reported by previous studies conducted on low birth-weight piglets (Furtado et al., 2012; Kummer et al., 2015; Moreira, 2015).

Presuming an average energy value of $1.49 \mathrm{kcal}$ $\mathrm{ME} / \mathrm{g}$ for colostrum and $91 \%$ efficiency of utilization in terms of total energy retention (Le Dividich et al., 1994; Le Dividich et al., 2005; Hurley, 2015), COS0 piglets ingested approximately $344 \mathrm{kcal}$ in the first day of their life. Thus, it can be concluded that energy requirements for maintenance, including thermoregulation, physical activity and growth, were adequately met in the case of the control piglets (with no extra nutritional support). It was surprising that the administration of extra $50 \mathrm{~mL}$ colostrum did not result in a greater colostrum intake as compared to the COSO and COS1 groups. During the study, we observed that after gavage feeding, the newborn piglets became satiated and did not seek the mammary gland for a while. Although this behavior was not systematically recorded, it is indicative of the fact that the extra colostrum seems to serve as an assurance for the newborn piglets rather than as an additional source of nutrient for improved performance.
Although nutritional supplementation, via colostrum or nutrient supplements, has been investigated as a possible strategy for improving the performance of low birth-weight piglets, in some studies this benefit has not been confirmed (Muns et al., 2014; Kummer et al., 2015; Moreira, 2015; Declerck et al., 2016). Kummer et al. (2015) tested two supplements (Biostart vitamin-mineral supplement; Lianol - protein supplement) in low birth-weight piglets (794 to $1,315 \mathrm{~g}$ ) within the first 8 hours of birth. Although Kummer et al. (2015) did not observe any positive effect of the supplementation on colostrum intake, serum IgG concentration, weight and ADG during the suckling period, they reported a reduction in the mortality rate by crushing and starvation when piglets received both supplements. When the same supplement used in the present study was previously tested, Moreira (2015) observed that low birth-weight piglets receiving $4 \mathrm{~mL}$ OPES within the first $24 \mathrm{~h}$ of life had a higher colostrum intake as compared to piglets that did not; however, no effect was seen on ADG throughout the suckling period. In contrast, our study indicated towards the presence of a small difference in ADG and weight between birth and weaning $(7 \mathrm{~g} / \mathrm{d})$, and weight (81g), in favor of piglets that received the supplement. This can be attributed to the fact that, as compared to the report of Moreira (2015), in our study a higher amount of OPES $(8 \mathrm{~mL}$ vs. $4 \mathrm{~mL})$ was administered in a much shorter period after birth (up to $4 \mathrm{~h}$ vs. up to $12 \mathrm{~h}$ ).

Regardless of the type of supplementation, almost $75 \%$ of all deaths were observed to occur within the first week of life, especially during the first $72 \mathrm{~h}$ ( $52 \%$ of death). It is known that the first few days after the birth is the time when piglets are the most challenged and hence it is common to observe a higher mortality rate in those days (Devillers et al., 2011; Kummer et al., 2015). The reports that discuss the effect of nutritional supplementation on the reduction of pre-weaning mortality have been subject to considerable controversy. Some studies have reported that supplementing newborn piglets with a supply of medium-chain triglycerides does not have a positive impact on survival rate (Benevenga et al., 1989; Lepine et al., 1989; Lee e Chiang, 1994). On the other hand, a reduced mortality rate was observed when piglets weighing 1000$1225 \mathrm{~g}$ at birth received a protein and/or mineral supplement (Kummer et al., 2015). 
Both time for the first suckling and the amount of ingested colostrum are important for ensuring the survival of neonatal piglets especially those with low birth-weight. The colostrum intake should begin within the first $60 \mathrm{~min}$ of birth (Decaluwé et al., 2014). During the first 24h of life, newborn piglets require approximately $170 \mathrm{kcal}$ net energy $/ \mathrm{kg}$ under the thermoneutral condition and $230 \mathrm{kcal} / \mathrm{kg}$ in cold conditions $\left(5^{\circ} \mathrm{C}\right.$ below thermal neutrality). Therefore, consumption of $160-170 \mathrm{~g}$ colostrum $/ \mathrm{kg}$ (Le Dividich et al., 2005) or 250g in total (Ferrari et al., 2014) are known to improve chances of survival and allow for an adequate growth profile during the suckling period. In the present study, the minimum amount of colostrum intake was attained in all the groups, which probably explains why a similar mortality rate was observed irrespective of colostrum and/or OPES administration. Indeed, a study by Moreira (2015) reported that OPES administration has a beneficial effect on the survival rate of low birthweight piglets when they receive a low amount $(120 \mathrm{ml})$ of colostrum.

The nutritional supplementation for low birthweight piglets was studied but no conclusive results could be drawn. More in-depth efforts are necessary in order to determine the exact time and amount of supplement that must be administered for optimal performance under field conditions. The use of colostrum supply entails some disadvantages such as the need for trained labor for gavage feeding, time-consuming efforts required for colostrum collection as well as extensive storage demands. Although commercial supplements are easier to handle, labor and costs required should be factored into their application potential.

\section{CONCLUSIONS}

Colostrum intake and pre-weaning mortality of low birth-weight piglets are not affected by nutritional manipulation through the administration of extra colostrum and/or a protein-energy supplement during the first hours of life. However, body weight gain during the suckling period and the weight at weaning were observed to be marginally improved by administration of the protein-energy supplement.

\section{REFERENCES}

BAXTER, E.M.; JARVIS, S.; D'EATH, R.B. et $a l$. Investigating the behavioral and physiological indicators of neonatal survival in pigs. Theriogenology, v.69, p.773-783, 2008.

BAXTER, E.M.; RUTHERFORD, K.M.D.; D'EATH, R.B. et al. The welfare implications of large litter size in the domestic pig II: management factors. Anim. Welfare, v.22, p.219238, 2013.

BEAULIEU, A.D.; AALHUS, J.L.; WILLIAMS, N.H.; PATIENCE, J.F. Impact of piglet birth weight, birth order, and litter size on subsequent growth performance, carcass quality, muscle composition, and eating quality of pork. J. Anim. Sci., v.88, p.2767-2778, 2010.

BENEVENGA, N.J.; STEINMANGOLDSWORTHY, J.K.; CRENSHAW, T.D.; ODLE, J. Utilization of medium-chain triglycerides by neonatal piglets: I. Effects on milk consumption and body fuel utilization. $J$. Anim. Sci., v.67, p.3331-3339, 1989.

CASELLAS, J.; CASAS, X.; PIEDRAFITA, J.; MANTECA, X. Effect of medium- and longchain triglyceride supplementation on small newborn-pig survival. Prev. Vet. Med., v.67, p.213-221, 2005.

DAMGAARD, L.H.; RYDHMER, L.; LØVENDAHL, P.; GRANDINSON, K. Genetic parameters for within-litter variation in piglet birth weight and change in within-litter variation during suckling. J. Anim. Sci., v.81, p.604-610, 2003.

DECALUWÉ, R.; MAES, D.; WUYTS, B. et al. Piglets' colostrum intake associates with daily weight gain and survival until weaning. Livest. Sci., v.162, p.185-192, 2014.

DECLERCK, I.; DEWULF, J.; DECALUWÉ, R.; MAES, D. Effects of energy supplementation to neonatal (very) low birth weight piglets on mortality, weaning weight, daily weight gain and colostrum intake. Livest. Sci., v.183, p.48-53, 2016.

DEVILLERS, N.; LE DIVIDICH, J.; PRUNIER, A. Influence of colostrum intake on piglets survival and immunity. Animal, v.5, p.16051612, 2011. 
DEVILLERS, N.; VAN MILGEN, J.; PRUNIER, A.; LE DIVIDICH, J. Estimation of colostrum intake in the neonatal pig. Anim. Sci., v.78, p.305-313, 2004.

FERRARI, C.V.; SBARDELLA, P.E.; BERNARDI, M.L. et al. Effect of birth weight and colostrum intake on mortality and performance of piglets after cross-fostering in sows of different parities. Prev. Vet. Med., v.114, p.259-266, 2014.

FOXCROFT, G.R.; DIXON, W.T.; DYCK, M.K. et al. Prenatal programming of postnatal development in the pig. Soc. Reprod. Fertil. Suppl., v.66, p.213-231, 2009.

FURTADO, C.S.D.; MELLAGI, A.P.G.; CYPRIANO, C.R. et al. Influência do peso ao nascimento e de lesões orais, umbilicais ou locomotoras no desempenho de leitões lactentes. Acta Sci. Vet., v.40, p.1077, 2012.

HURLEY, W.L. Composition of sow colostrum and milk. In: FARMER, C. (Ed.). The gestating and lactating sow. Wageningen: Wageningen Academic Publishers, 2015. p.193-229.

KUMMER, A.D.; BARONCELLO, E.; MOREIRA, L.P. et al. Efeitos do fornecimento oral de suplementos nutricionais na sobrevivência e crescimento de leitões de baixo peso ao nascer. Acta Sci. Vet., v.43, p.1336, 2015.

LE DIVIDICH, J.; HERPIN, P.; ROSARIOLUDOVINO, R.M. Utilization of colostral energy by the newborn pig. J. Anim. Sci., v.72, p.2082-2089, 1994.

LE DIVIDICH, J.; ROOKE, J.A.; HERPIN, P. Nutritional and immunological importance of colostrum for the new-born pig. J. Agric. Sci., v.143, p.469-485, 2005.

LEE, H.F.; CHIANG, S.H. Energy value of medium-chain triglycerides and their efficacy in improving survival of neonatal pigs. J. Anim. Sci., v.72, p.133-138, 1994.

LEPINE, A.J.; BOYD, R.D.; WELCH, J.A.; RONEKER, K.R. Effect of colostrum or medium-chain triglyceride supplementation on the pattern of plasma glucose, non-esterified fatty acids and survival of neonatal pigs. J. Anim. Sci., v.67, p.983-990, 1989.
MOREIRA, L.P. Leitões de baixo peso ao nascimento: alternativas para garantir a sobrevivência, imunidade e bom desempenho na fase de maternidade. 2015. 70f. Dissertação (Mestrado em Ciências Veterinárias) Faculdade de Veterinária, Universidade Federal do Rio Grande do Sul, Porto Alegre, RS.

MORISE, A.; LOUVEAU, I.; LE HUËROULURON, I. Growth and development of adipose tissue and gut and related endocrine status during early growth in the pig: impact of low birth weight. Animal, v.2, p.73-83, 2008.

MUNS, R.; SILVA, C.; MANTECA, X.; GASA, J. Effect of cross-fostering and oral supplementation with colostrum on performance of newborn piglets. J. Anim. Sci., v.92, p.11931199, 2014.

PANZARDI, A.; BERNARDI, M.L.; MELLAGI, A.P. et al. Newborn piglet traits associated with survival and growth performance until weaning. Prev. Vet. Med., v.110, p.206-213, 2013.

QUESNEL, H.; FARMER, C.; DEVILLERS, N. Colostrum intake: Influence on piglet performance and factors of variation. Livest. Sci., v.146, p.105-114, 2012.

QUESNEL, H.; FARMER, C.; THEIL, P.K. Colostrum and milk production. In: FARMER, C. (Ed.). The gestating and lactating sow. Wageningen: Wageningen Academic Publishers, 2015. p.193-229.

QUINIOU, N.; DAGORN, J.; GAUDRÉ, D. Variation of piglets' birth weight and consequences on subsequent performance. Livest. Prod. Sci., v.78, p.63-70, 2002.

SALMON, H.; BERRI, M.; GERDTS, V.; MEURENS, F. Humoral and cellular factors of maternal immunity in swine. Dev. Comp. Immunol., v.33, p.384-393, 2009.

STATISTICAL analysis system. Version 9.4. Cary: SAS Institute, 2010. 